\title{
Climate Change Influence on Agriculture and the Water-Energy-Food Nexus in Central and Eastern European Countries
}

\author{
Camelia KANTOR ${ }^{1}$, Ewen MCLEAN ${ }^{2}$, Mihai KANTOR ${ }^{3 *}$ \\ ${ }^{1}$ United States Geospatial Intelligence Foundation (USGIF), 2325 Dulles Corner Blvd, Suite 450, Herndon, VA 2017, \\ USA; camelia.kantor@usgif.org \\ ${ }^{2}$ Aqua Cognoscenti, West Columbia, SC, 479 Henslowe Lane, West Columbia, SC 29170, USA; ewen.mclean@gmail.com \\ ${ }^{3}$ Claflin University, 400 Magnolia Street, Orangeburg, SC, USA; mkantor@claflin.edu (*corresponding author)
}

\begin{abstract}
The Water-Energy-Food (WEF) Nexus concept has great potential for understanding a region's vulnerability to climate change. This paper examines individual components that form the supporting pillars of the nexus in Central and Eastern European (CEE) countries. An overview of specific CEE political environments that govern economic and environmental policies are examined to select several domains representing higher risks to society, environment and economies of selected countries, together with evaluation of extant interlinkages between climate change, agriculture and the WEF nexus. While a variety of studies quantify and analyze climate change impacts on water availability, crop yields, yield variability, or alternative energy needed to mitigate global warming effects, this paper shows there is no clear evidence of a nexus-based integration to help manage or mitigate extreme future climate change-related events in the region. The study provides a model for supporting WEF pillars and advances recommendations for consideration of the nexus approach in relation to climate adaptation.
\end{abstract}

Keywords: climate adaptation, food production, land-use, policy, sustainability, WEF nexus

\section{Introduction}

Since the 2004/7 eastward expansion of the European Union (EU), research related to agricultural reforms and their ecological impacts in Central and East Europe (CEE) has climbed sharply (Stoate et al., 2009). And, since sustainable economic growth and public wellbeing are indelibly linked to water, energy and food (WEF) security (OECD, 2014), researchers, business leaders and policy makers have embarked on a path to better understand how the interconnections of the WEF nexus may impact policy development and implementation (Leck et al., 2015). This already intricate task is further complicated not only by shifts in population, but also by climate change which increases competition for resources and may threaten food security (Bizikova et al., 2014). Herein, climate change trends, and the political and economic context of agriculture in CEE countries, are examined to identify the extent that WEF components are considered to support decision-making and climate change mitigation.

Food, water and energy are managed/priced according to political economies and are highly significant in establishing emotional relationships between society and the government that is responsible for their security (Allan et al., 2015). Thus, an overview of specific CEE political environments that govern economic and environmental policies are examined to select several domains representing higher risks to society, environment and economies of selected countries, together with evaluation of extant interlinkages between climate change, agriculture and the WEF nexus.

\section{Geographic area considered}

The geographic region of CEE has witnessed significant turmoil in national boundaries with sixty percent of current borders being drawn during the 20th century (Foucher, 1998); indeed, 8000 miles of new state line have appeared since 1989 (O'Dowd, 2002). Herein, however, attention centers on six of the ten countries listed by the UN under the "developed region" (UN, 2016) Europe-Eastern Europe (area code \#151, Fig. 1), viz. member states of the European Union (EU): Bulgaria, Czech Republic (former Czech Republic), Hungary, Poland, Romania, and Slovakia.

Taken alone, Eastern Europe is too heterogeneous to allow for a more in-depth analysis, especially when the Russian Federation and Ukraine are included, because these nations play significant roles in relation to national security and in the international food and energy markets; they have potential to significantly skew economic, social, and 


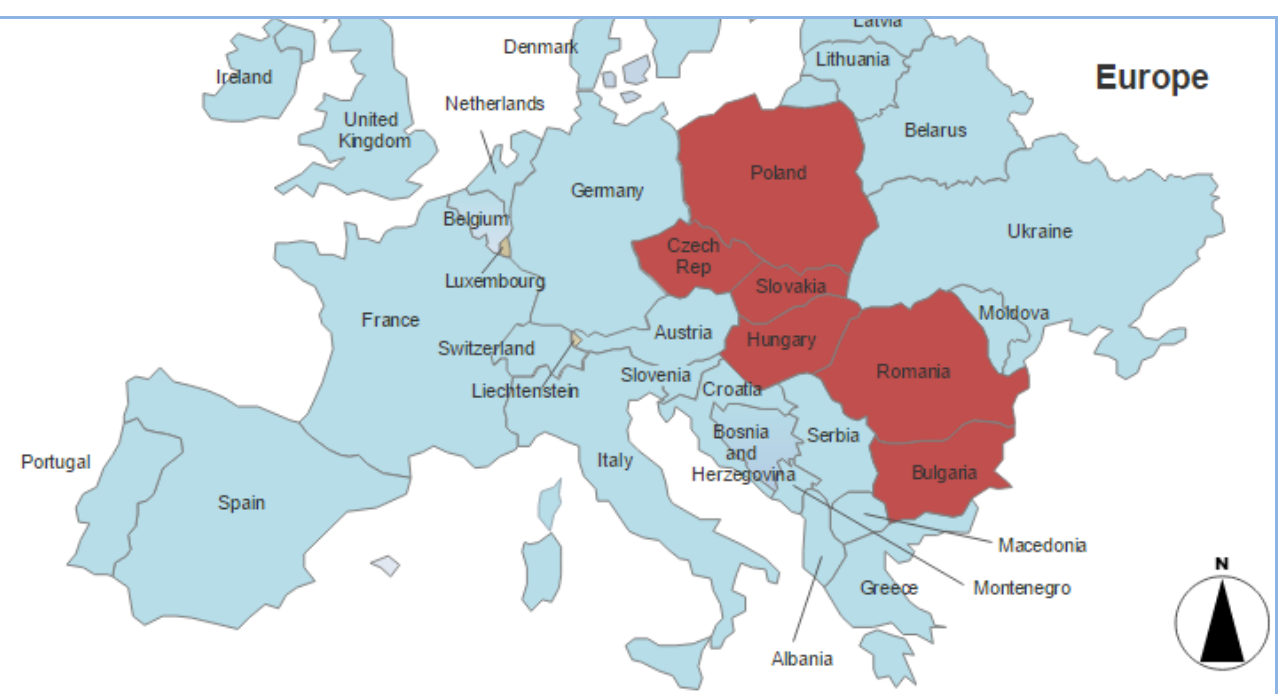

Fig. 1. Nations of Central and Eastern Europe. Red shaded; UN area code \#151, Bulgaria, Czech Republic, Hungary, Poland, Romania, and Slovakia considered in the present study (Source: the authors)

environmental data analyses. In addition, Slovenia, another EU member, is treated here more as a buffer country, a gateway between Central Europe and the Balkans while Czech Republic, advantaged economically due to its geographic position, represents a gateway between the West and the East. As part of the Balkans sub-region, only two EU member states are counted, namely Bulgaria and Romania. When considered as a region, Czech Republic, Hungary, Slovakia, and Poland will be referred throughout as "Central Europe". Geographical location plays a major role in the region's agrarian development since countries closer to the West are advantaged despite being equipped with similar or even fewer resources needed to insure successful agriculture.

Political and economic environment for sustainable agriculture in CEE

Until 1989 Eastern European countries were united by their political regimes and very similar economic structure as part of the Council for Mutual Economic Assistance or "Comecon" system (Swinnen and Van Herck, 2013). Comecon was founded in 1949 to stimulate several socialist economies and to increase economic prosperity and efficiency. Despite its noble goal, Comecon's lack of success was due to its tight state planning and national egotism (Dale, 2016). During this period, the agricultural sector functioned under a collectivization policy, which was associated with higher yields but also with unfavorable changes in land use and cropping patterns, leading to acidification, soil erosion, salinization and chemical pollution (Bouma et al., 1998). When this system disintegrated in 1989, Eastern Europe experienced a dramatic shift, becoming more heterogeneous and recording different levels of economic growth. Central European countries had a jumpstart and joined the EU 3years earlier than Balkan countries. Progressively, until 2007 when Romania and Bulgaria joined the EU, all Balkan states became fully-fledged democracies (Swinnen and Van Herck, 2013). Socio-political history, coupled with lack of access to technology, represented limitations for industrial agriculture while the region began to be concomitantly valued for its specific landscape character (Sutherland et al., 2014). Although sharing the legacy of communist agricultural policy, national economic development outcomes varied among states with geography playing an important role. Czech Republic, for example, neighboring Germany and Austria, had an advantageous starting point for successful transition (Svejnar, 2013). Poland, supported by the same two countries (especially Germany), increased gross agricultural output significantly in real terms over the period 2000 to 2011 (Csaki and Jambor, 2013), and was the only country to increase numbers of agricultural employees following EU accession (Csaki and Jambor, 2009).

As demonstrated by Gerdessen and Pascucci (2013), it is very difficult to measure the concept of sustainability of a regional agricultural system due its complexity and variety of possible approaches. Still, there seems to be a consensus over the inclusion of three elements, namely: a feasible economic dimension, an acceptable social dimension, and an environmental dimension (Gerdessen and Pascucci 2013). A similar structure is followed here as the three dimensions of sustainability were used to incorporate four variables selected from the 45 indicators identified by the European Commission to describe how policy measures are designed, planned and implemented (CAP 2011, CAP 2007-2014, and CAP 2014-2020). These were: Gross Value Added (GVA), Standard of Living, Farm Input Intensity and, High Efficiency Agricultural Systems.

The share of agriculture, in terms of Gross Domestic Product (GDP), provides a good estimation of its importance to a nation's economy. For example, Bulgarian and Romanian agriculture represents $14 \%$ and $13 \%$ of GDP respectively; but each country has also recorded greatest declines in production since joining the EU. In the CEE region Poland, Romania and Hungary are the principal agricultural producers (Csaki and Jambor, 2009). In most cases, the return of land to private ownership in CEE countries has led to the creation of small semi-subsistence holdings (generally $<5$ ha in size) and only a few very large industrial farms (Davidova et al., 2012; Sutcliffe 2015). 
Overall agricultural productivity dropped dramatically in the CEE and large areas of both cropland and grassland were abandoned in the 1990s and early 2000s (Sutcliffe et al., 2015). Indeed, in most countries transitioning their economies after 1989, agricultural output dropped 25-50\% (Macours and Swinnen, 2000; Liefert and Swinnen, 2002), with price liberalization and subsidy cuts being the major contributors to the decline, followed by a $10 \%$ output fall caused by severe drought (Macours and Swinnen, 2000).

Unlike its Balkan neighbors (Romania and Bulgaria), agriculture is of little importance to Slovenia, contributing less than 3\% to its GDP. In addition, Slovenia represents a special case scenario since $99 \%$ of its agricultural assets are privately owned, thereby preserving traditional family farming (Erjavec, 2005).

Overall, there is general agreement that before joining the EU the CEE area's agriculture was characterized by a high incidence of small-scale farmers who were not producing for the market (Mathijs and Noev, 2004). These family farms or "home gardens" were expected to decrease in number after joining the EU, with farmers located in less isolated areas switching to lower levels of agricultural biodiversity to insure food security (Smale, 2005). However, while marginal agricultural land was abandoned, the remainder experienced intensification (Verhulst et al., 2004). A 2012 study in five new EU member states suggested that the largest cluster continues to be formed by the poorest households with "low natural, physical, and social capital, operating small-scale and undercapitalized farms with little nonagricultural income" (Davidova et al, 2012). The same study concluded that the specific needs of these poor subsistence farmers are not met by instruments of the EU Common Agricultural Policy (CAP) (Davidova et al., 2012). The CAP represents the EU's most important common policy, taking also a large percentage of the EU's budget (European Commission, 2017). Established in 2007, the European Agricultural Guarantee Fund (EAGF) replaced the earlier European Agricultural Guidance and Guarantee Fund. EAGF provides direct payments to farmers as well as regulating agricultural markets through national governing bodies which, in turn, regulate internal agencies (e.g., APIA in Romania; EFGR in Poland).

Other sources suggest that EU accession has had a significant impact on agriculture in new EU member states, although they capitalized their opportunities in different ways (Csaki and Jambor, 2009, 2013). Except for Poland and Slovenia, the two countries that had a consolidated and advantageous farm structure to start from, factors such as different agricultural policy frameworks, restrictive land policies, uneven CAP support and supplement payments, increasing competition with limited domestic market capacity to withstand such strains, negativist attitudes regarding the attractiveness of the economic sector, and the degree of investments (see detailed data in Csaki and Jambor, 2009, 2013; Ciutacu et al., 2015) seemed to impact country performances and created different outcomes. In the case of Bulgaria and Romania, for example, even if pre-accession (PHARE, ISPA, SAPHARD) and post-accession funds were significant, they struggled to keep up with disbursements as seen in other CEE countries (Paliova and Lybek, 2014).
Further reasons, such as redistribution of labor to other economic branches - a long-time process going back to 1950s, and sustained migration to urban areas, followed by EU labor migration after EU accession, further contributed to the creation of a "deeply imbalanced, dysfunctional, and non-competitive" agricultural sector (Ciutacu et al., 2015) in countries unable to create a successful transition and implementation framework.

\section{Gross Value Added (GVA)}

Statistic measures agriculture's contribution to a total economy gross value added, being calculated as output minus intermediate consumption. Agricultural producers are highly dependent on public support. In 2014, GVA at producer prices in the studied area was highest in Poland followed by Romania. Therefore, these two countries were expected to receive the highest level of subsidies like Western EU members (Germany, France, Italy). The lowest GVA was registered in Slovakia, Slovenia, and Czech Republic. In the East, however, the distribution of public support did not follow the Western model: Slovakia, Slovenia, and Czech Republic received significantly higher levels of subsidy when compared to Romania or Poland (CAP 2013).

\section{Standard of living}

One of the principal objectives of the CAP is to provide farmers with a reasonable standard of living. Common context indicator (CCI) 26-Agricultural entrepreneurial income is calculated based on two units of measurement: (1) Standard of living of farmers, measured as net agricultural entrepreneurial income in real terms per non-salaried annual work unit and, (2) Standard of living of farmers, measured as share of the standard of living of employees in the whole economy based on $€$ per hour worked (European Communities, 2014).

Fig. 2 shows farmer standard of living as measured as a percentage change in income per family work unit between 2007-2014 in the nations of Central and Eastern Europe considered in the present study. When looking at the Common Context Indicator (CCI) \# 26 Agricultural entrepreneurial income data per family work unit for the period 2007-2014, there is a significant discrepancy between Western and Eastern EU members. All the Eastern European countries considered in this study (except Slovenia that had a slight increase) registered significant decreases in agricultural entrepreneurial income per family work unit between 2007 and 2014; Romania and Bulgaria entered the EU in 2007. When comparing income per agricultural family worker to national average wages, four out of seven countries registered a decrease since 2007. Interestingly, the highest wage increase was recorded in two of the three countries with lowest GVA, but higher subsidy levels (Czech Republic and Slovenia), while the worst affected countries were Hungary, Bulgaria and Poland. Coupled with the fact that birth rates are declining in most of the developed world, as children had become an economic liability rather than an economic asset to families, farming is not an attractor to the future workforce, with more people leaving agricultural professions and moving to urban areas. 


\section{Farm input intensity}

an agri-environmental indicator, is a common context gauge for rural development programs. Based on the Eurostat statistics definition (Eurostat, 2016), intensification of farming, which is the process of increasing the use of capital and labor (e.g. fertilizers, pesticides, machinery), relative to land area, to increase agriculture production per hectare (ha), is defined as the increase in farm intensity, while extensification describes the opposite trends (Eurostat 2016). When looking at farmed area (UAA) managed by farms with low input intensity per ha, Romania and Bulgaria still have the highest percent of total UAA (at $80 \%$ and $61 \%$ respectively), followed closely by Hungary (at 52\%). Again, Czech Republic is closer to Western EU states at only 24\%. While development of low farm intensity is a priority for a sustainable future (Pointereau et al., 2012), the overall trend in the region is intensification (Eurostat 2016, agri-environmental indicator-intensification-extensification, Nov. 2012), the high percentages of low input intensity being attributable to the economic size of farms in these countries. Despite its average payment of $237 € \mathrm{ha}^{-1}$ of farmland in the last programming period, the CAP efforts to support EU farming through subsidies barely achieved subsistence and semi-subsistence holdings that make up such a large proportion of CEE farms (Sutcliffe et al., 2015). Thus, farm abandonment or intensification might become the only and best option available. Time will show if the planned single payment in the 2014-2020 CAP for "small farms", has the potential to improve the financial situation of these holdings. Concomitantly, along with low input intensity, there is need for high efficiency agricultural systems commonly linked with farmer skills and global coherence of farm management (Pointereau et al., 2012).

\section{High efficiency agricultural systems}

Efficiency involves farmer skills and management knowhow to allow for improved practices such as pesticide reduction, nitrogen management, nutrient balances, use of renewable energy, adaptation to climate and soil modifications (erosion, fertility) and improvements in farming systems such as biological control, crop rotation, crop diversity, breeding and ecological infrastructures (Pointereau et al., 2012). When examining the latest Eurostat statistics, Romania and Bulgaria have the highest percentage of farm managers with limited practical experience at 96 and $93 \%$ respectively. At the opposite end of the spectrum, Czech Republic has the highest percentage of farm managers with full agricultural training (34.6\%), significantly higher even than western EU members, with strong agricultural traditions, such as Germany or France. While Slovenia still has $50 \%$ of farm managers with limited practical experience, of these, $76 \%$ have received basic and $24 \%$ full agricultural training. Poland has a similar situation with 40 and 55\% respectively. If the low level of agricultural training in Romania and Bulgaria is perceived as "structural difficulty" (Ferńndez, 2002) it represents a significant obstacle to improving productivity, accessing funding, and preserving the environment. Added to this, the aging structure of farm managers in the EU denotes a reason for concern over the future of agriculture. Except for Poland and Austria, all other EU members have fewer than $10 \%$ of

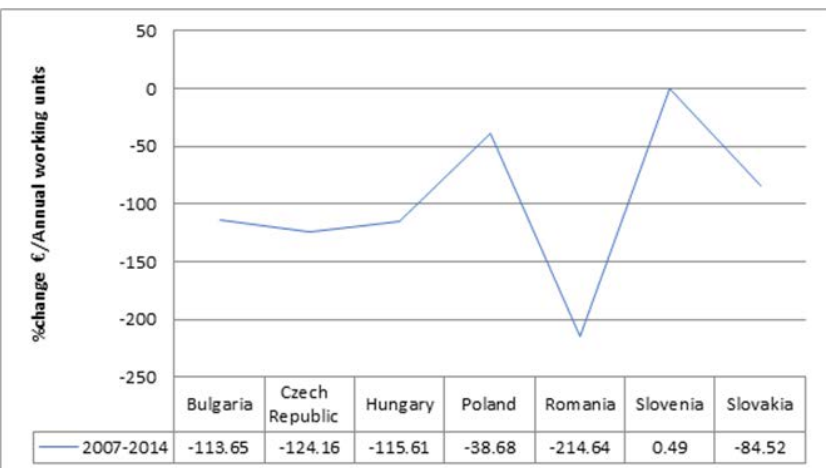

Fig. 2. Farmer standard of living as measured as a percentage change in income per family work unit (based in real terms on percent change in $€$ per average work unit) in between 2007 2014 in the nations of Central and Eastern Europe considered in the present study (Source: European Commission, DG Agriculture and Rural Development, CAP context indicators 2014 and 2015)

their farm managers of 35 or less years of age. Indeed, more than half are 55 years and older in Romania (64\%), Bulgaria (62\%), Hungary (60\%), Czech Republic (57\%), Slovenia (54\%) and Slovakia (52\%).

In summary, based on the four selected indicators, all but two Eastern European countries (Czech Republic and Slovenia, both advantaged by their geographic location) are facing significant challenges in sustaining their agriculture concomitantly with their economic and demographic problems. Low levels of subsidies, decreasing standards of living for an aging population of farmers, small numbers of farm managers with at least basic training in modern agricultural practices, reduced economic size of farms with produce mostly self-consumed by household members, all suggest a dire prospect in relation to the future of agriculture in this region and contribute to significantly lower chances of high productivity and resource efficiency to meet the needs for sustainable regional food security. To address these problems more investment is needed in countries with higher GVA and percent total UAA to insure positive effects on the agricultural economy through improvements in farm-input intensity, farming efficiency, and farmers' standards of living.

\section{Climate change and agriculture}

One of the greatest challenges facing humanity today is how to adapt to climate change and manage the effects of global warming (Rasul and Sharma, 2015). Climate is often characterized by surface variables such as air temperature, precipitation, radiation, humidity, cloud cover, and wind (Anders et al., 2014). Climate change is defined as a change in the state of the climate that can be identified by modifications in the mean and/or the variability of its properties together with persistence, which may be for decades or longer (Bernstein et al., 2008). As mentioned by NASA, the evidence for rapid climate change is "compelling" (NASA, 2017) and agriculture represents a sector of national economies strongly influenced by climatic conditions (Błażejczyk et al., 2015); as well as being a primary driver of change (Rockström et al., 2017). 
Adaptation to climate change requires modifications to current agricultural systems to meet new challenges; changes that need to be embraced even by modern agriculture (Carof et al., 2012). In countries where agriculture is still characterized by lack of modern equipment and technologies these challenges are even more prominent as daily weather conditions represent an important factor in farming efficiency, intensity, and health risks in farmers performing mostly outdoor jobs. Similarly, as plants consume large amounts of water, warmer climates make possible a greater amount of evaporative water use, thus leading to water shortages. Furthermore, extreme precipitation events create wet conditions responsible for mass movements such as landslides and mudflows as well as surface-accelerated erosion detrimental to agricultural soil; events particularly severe where agriculture has replaced forestry. Climate change may also be associated with increased occurrence of diseases and pest pressures (Eitzinger et al., 2013) or shifts in the ranges of pest species to higher altitudes (Svobodová et al., 2014).

In a 2013 study, it was predicted that significant agroclimatic changes would affect future agricultural crop production in the CEE region (Eitzinger et al., 2013). Similarly, the latest IPCC report (IPCC, 2015) provides multiple lines of evidence to support significant climatic changes between 2081-2100. One of the most valuable contributions to understanding, homogenizing, and assessing the existent climatic databases covering large territories in the CEE is represented by the Climate of the Carpathian Region (CARPATCLIM) project, 2016. The Carpathian Mountain Region (CMR) covers seven countries of Central and Southeastern Europe (Czech Republic, Slovakia, Hungary, Poland, Ukraine, Romania and Serbia) (Birsan et al., 2014). Each of these countries has contributed data to the CARPATCLIM, for the period 1961-2010, from ground-based meteorological stations. The variables considered included: maximum and minimum air temperature, precipitation amount, average and maximum wind speed, sunshine duration, cloud cover, global radiation, relative humidity, air pressure, water vapor pressure and snow depth (Cheval et al., 2014). Based on CARPATCLIM information and the European Climate Assessment \& Datasets (ECA\&D), Cheval et al. (2014) summarized and analyzed trends in all the variables. Because precipitation, air temperature, and drought events have the highest potential to significantly influence regional agricultural output, these three variables are considered herein.

\section{Changes in precipitation}

In recent years, Bulgaria, Czech Republic, Hungary, Poland, Romania and Slovakia, have all experienced lower precipitation (Alexandrov and Genev, 2003; Domonkos, 2003; Alexandrov et al., 2004; Degirmendžić et al., 2004; Kyselý, 2009; Chenkova and Nikolova, 2015; Portela et al., 2017). Kyselý (2009) remarks that temporal changes are generally more pronounced in the western than eastern part of Czech Republic and that the pattern of change is more complex and less coherent in eastern than in western Europe. In Hungary, annual precipitation decreased by 15 $20 \%$ during the 20th century, with the country's summer moving to a more Mediterranean-like climate (Domonkos,
2003). Croitoru et al. (2016), examined Romanian precipitation trends between 1961-2013 and reported a wetter climate, especially in the north of the country, due to increased precipitation magnitude and with decreasing trends in the southern region of the country (Micu et al., 2016). This is like the situation in Czech Republic, where precipitation differs significantly between its western and eastern regions (Kyselý, 2009). Similar decreasing trends in annual, and especially summer precipitations, were identified in Bulgaria, Romania's southern neighbor (Chenkova and Nikolova, 2015; Alexandrov et al., 2004; Alexandrov and Genev, 2003). Overall, there is an increasing trend for extreme precipitation events in the region, with higher precipitation magnitudes and frequencies, but generally decreasing precipitation, relatively low spatial coherence of precipitation indices, and longer dry periods projected for the future (Cheval et al., 2017).

\section{Air temperature}

Changes in air temperature in different regions of Europe have shown upward trends, with frequent occurrence of extremely hot months, especially during summertime (Tomczyk and Bednorz, 2016). In Central Europe, the average number of hot days has increased over the past ten years, occurring mostly between April and October and with maxima in June through August (Tomczyk and Bednorz, 2016). Heat waves (HW), characterized by persistence of hot days over a period of time (usually five days or more), may have significant negative social and agricultural effects. They have become common during summertime in Bulgaria and south Romania (Simeonov et al., 2013), with dangerous impacts on agriculture associated with increased heat stress episodes. As recently presented at the EU General Assembly 2016, the summer of 2015 was the warmest ever observed in Central Europe, especially due to overall severity of HW (Lhotka et al., 2016), continuing the trend identified by Tomczyk and Bednorz (2016) of significantly increased numbers of HW between 2001 and 2010 as compared to 1981-1990. Similarly, according to Birsan et al. (2014), the CMR has witnessed decreasing trends in cold-related indices, especially in the number of frost days, and increasing trends in warm-related ones. In addition, the number of summer days and daily maximum temperatures (Warm Spell Duration Index) has also increased, especially at lower elevations (Birsan et al., 2014). Busuioc et al. (2015) suggest the influence of the Carpathians over both temperature and precipitation extremes in the region. For example, after computing ten indices associated with six temperature extremes and four precipitation extremes over the period 1961-2010 in Romania, they found significant increasing trends for the six temperature extremes with higher values over the southern and eastern region in winter, and over western, southern and southeastern regions during the summer.

\section{Drought}

Decreasing precipitation trends and increasing regional air temperature lead to increased risk for droughts. Recognized among the major contributors to natural disasters, droughts have the potential to negatively impact the socio-economic condition of people living in drought- 
454

prone areas. Droughts have adverse effects on water availability and quality, agricultural and energy production, and ecosystem health (Bokal et al., 2014). To address the region's vulnerability to drought, the CEE of the Global Water Partnership (GWP) launched a regional Integrated Drought Management Programme (IDMP) for 2013-2015 as part of the global joint World Meteorological Organization (WMO)/GWP IDMP. Bulgaria, Hungary, Moldova, Romania and Slovenia were founder members of the Drought Management Centre for South-Eastern Europe (DMCSEE) established in 2006 by WMO and UNCCD. In these countries, agriculture is the most vulnerable sector to drought (Bokal et al., 2014). According to Spinoni et al. (2016), CEE has a tendency to exhibit more intensive drying, mainly in spring (Central Europe) and autumn (Eastern Europe) for drought frequency and in all seasons for drought severity. Bulgaria and southern Romania appear particularly vulnerable to water scarcity and drought events and Popova et al. (2015), in their study of eight Bulgarian climate regions for 1951-2004, confirmed that agricultural lands had experienced increased vulnerability to water stress.

While Europe overall is not expected to have large problems with self-sufficiency (Fader et al., 2013), projections to 2050 indicate that the CEE will experience the highest increase in competition for water, especially in Bulgaria, Romania and Poland (Stigson et al., 2014; Popova et al., 2015). The climate signal regarding precipitation extremes is not as clear as for temperature extremes (Busuioc et al., 2015), showing a great regional variability. Significant increases in the summer frequency of very warm days, and in the maximum length of dry intervals has been determined with higher anomalies in the southern regions of the countries examined. It is important to note, however, that temperature criteria that may be the norm in a type A climate has the potential to be considered extreme in a type $\mathrm{C}$ climate; leading to significant imbalances in the social, economic, and political arenas. Extreme climate change-associated weather events may lead to a substantial increase in agricultural risk and unstable farming outcomes. Temperature changes may alter weather patterns, which may reduce agricultural outputs and influence energy needs that have the potential to lead to increased economic instability (Bokal et al., 2014).

\section{Management of natural resources and land use practices}

Here we consider three essential natural resources: soil, air, and water and countries that plan to manage their lands sustainably need to focus efforts on mitigating the potential negative impacts that management activities may have on these resources. In the CEE region, accession to the $\mathrm{EU}$ has been accompanied by governance directives, quality control and corruption mitigation action plans for managing natural resources. But, despite such measures, natural resource management still spills over regulatory, spatial, and bureaucratic boundaries (Salukvadze, 2010), especially when value outweighs the risks. The development and implementation of policies and decision-making regarding Agriculture, Forestry, and Other Land Use (AFOLU), known to be a significant source of greenhouse emissions, constitute a major challenge in CEE where, compared to
Western European countries, biodiversity is higher but research budgets lower (Mihók et al., 2015). Globally there is robust evidence that AFOLU accounts for close to $15 \%$ of anthropogenic GHG emissions, mainly from deforestation and agricultural emissions from livestock, soil and nutrient management (Smith et al., 2014); although there is considerable variation between countries (MacLeod et al., 2015). Anthropogenic forest degradation and biomass burning (forest fires and agricultural burning) represent additional contributors. Unfortunately, agricultural systems continue to degrade land, water, biodiversity and climate on a global scale, impacting world food security and sustainability needs (Foley et al., 2011). On the positive side, while worldwide sustainable agricultural intensification has dramatically increased in recent decades (Foley et al., 2011; Rockström et al., 2017), the CEE region's legacy of communist agricultural policy has led to lower average levels of land use intensity, affecting not only the structure and use of farmland, but also better preserving farmland biodiversity, which has been lost in the West (Sutcliffe et al., 2015). Even today, in some of the CEE countries, farming and pasture are managed as they were in the past (PătruStupariu et al., 2015).

On the negative side, however, farm intensification has been encouraged in the CEE through EU CAP funding and implemented based on "imported EU policies" that may not fit regional or local conditions (Sutcliffe et al., 2015), placing CEE at risk of future unsustainable agricultural practices. The return of land to private hands, after the fall of communism in the CEE, has further contributed to the predominance of small, subsistence farming, with many areas of cropland or grassland (especially marginal ones), being abandoned. As evidenced by a recent study conducted by Pătru-Stupariu et al. (2015), land-tenure and social changes, land use intensification, and foreign investments are three out of the top five causes of landscape changes identified through remote sensing in Romania as presented by local stakeholders. The same study identified some of the factors that have impacted these three categories, including but not limited by:

- Change in land tenure to private ownership has created boundaries to animal grazing, also leading to the abandonment of marginal and/or poor soils from large pasture lands;

- Consistent to the prior observations on farmers' Standards of Living, young farmers' migration to cities in search of more desirable employment has further contributed to farmland abandonment;

- Increasing government subsidies for agriculture and livestock, especially subsidies for pasture maintenance (Hartel and Plieninger, 2014), and use of fertilizers monitored through remote sensing technology, has led to land use intensification.

Limited regulations and control of forest restituted areas, added to a lack of reforestation culture (previously mandated during the restrictive dictatorial regimes), and periods of economic hardships due to bankrupt industries, have further accelerated the deforestation process (PătruStupariu et al., 2015). Approximately 166 million ha have 
been already degraded by erosion of topsoil, compaction, fertility decline, and crusting in CEE (Batjes, 2002). Deforestation is one of the major contributors, where biomass is still heavily utilized by the residential and tertiary economic sectors (household, hotel, schools and hospitals' heating and in and other public buildings; Scarlat et al., 2011).

It is fascinating to observe the dichotomy of this region: on one hand, as EU member states, CEE countries must comply with EU environmental protection laws and, therefore, encourage sustainable agriculture. On the other hand, due to high land prices in the EU, the CEE neighbors have become more attractive for agricultural production (Salukvadze, 2010), thus leading to threatened ecosystems because of intensified agriculture. Similarly, bound to following EU subsidy streams, the CEE countries may miss opportunities for integrating economic development projects with environmental protection efforts. For example, while abandoned farmland has become less widespread in CEE as compared to its eastern non-EU members (Ukraine, Russia), increased land-use change for biodiesel or ethanol production in several countries of the CEE did not happen on the available set-aside/abandoned land. As evidenced by literature, increased agricultural bioenergy crop production may have a significant impact on land use increase and pattern changes, with potential high C losses when native vegetation is converted to annual crops (Banse et al., 2008; Don et al., 2012; Vasile et al., 2016). CEE are particularly at risk given that they encompass substantial cultivated areas that can be freed up through sustainable gains in yield in the food and feed sector (Fischer et al., 2010). Poland, Czech Republic, Hungary and Slovakia have significantly increased their ethanol and/or biodiesel production (Fig. 3) since 2005 (except Slovakia with high biodiesel but decreased ethanol production). Romania also increased its ethanol production with rape, sunflower and soybean (annually cultivated herbaceous energy crops) cultivated areas replacing land cultivated with cereals; this has also attracted new land into production (Vasile et al., 2016). While one cannot yet largely consider competition for scarce arable land between energy and food markets in CEE, the regional distribution of bioenergy crops may change the dynamics in this region, which is why biofuel production should be managed to improve both food security and farm income.

\section{The Water-Food-Energy Nexus (WEF)}

Based on the Köppen-Geiger climate classification, CEE countries are mostly located in Type $\mathrm{C}$ climates (moderate and temperate); areas that are usually the most productive but also vulnerable to serious deforestation, water pollution, increased extreme weather events, and soil erosion (Bokal et al., 2014). Land use intensification, farm land abandonment, lack of farmer training in soil conservation technologies and fertilizer utilization, and increased use of fertile cropland for bioenergy crops in direct competition with food production are some major problems identified for the CEE region (Salukvadze 2010; Don et al., 2012; Bokal et al., 2014; Pătru-Stupariu et al., 2015). It is safe to affirm that, based on the available research conducted in the area, that the CEE is already facing challenges in terms of reversing natural resource degradation, and adapting their farming techniques to water scarcity and global climate change (Bokal et al., 2014).

As suggested by Rasul and Sharma (2015), effective adaptation to change entails efficient use of land for agricultural production and of water and energy to insure food security. The WEF security concept has been gaining increased interest in the past years in the West and elsewhere, but is still almost non-existent in CEE planning when considering the lack of studies listing all three elements and their interconnectivity. Even in the western world this relationship has been investigated only comparatively recently (2014) by the U.S. Chamber of Commerce Foundation (USCCF) followed by a surge in WEF-related research. USCCF found that systematically addressing resiliency to nexus challenges requires the following steps: understanding connections, surveying and data collecting to understand resources, assessing risks and opportunities, implementing technologies and programs, collaborating with stakeholders and leading the change. While climate change effects are not yet as noticeable in the CEE region, there is enough evidence that this region may be facing significant challenges in insuring the three components of the nexus for its population in the future (Bokal et al., 2014; Cheval et al., 2014; Marin et al., 2014; Pătru-Stupariu et al., 2015).

Early adaptation actions would require an integrated approach where WEF are considered together to insure security (Olsson, 2013) and mitigate the impacts of climate change. The goal of adaptation is to reduce vulnerability to both climatic and non-climatic changes (Rasul and Sharma, 2015) by focusing on three major elements of the nexus, namely forests (a major fuel resource and a source of building material in the region), fresh water supplies, and agricultural soils (Bokal et al., 2014). In addition, there are three supporting pillars that the nexus needs, including: (1) reliable and sustainable transportation infrastructure; (2) well developed meteorological, geological, and hydrological monitoring and; (3) targeted funding for farmer support (training, loans, technology transfer and quality of life support). Implementation projects should demonstrate concerted efforts to insure the presence of all three nexus components (Fig. 4).

As part of the model (Fig. 4), in order to successfully manage resources, the ability to transport food supplies safely and rapidly is of major importance to the nexus.

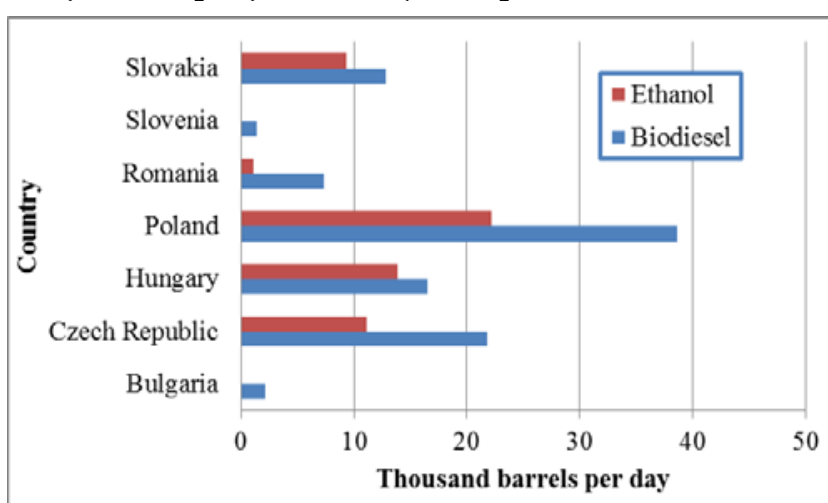

Fig. 3. Production of biodiesel and ethanol in CEE from 2005 to 2012 (Source: authors based on United States Energy Information Administration) 


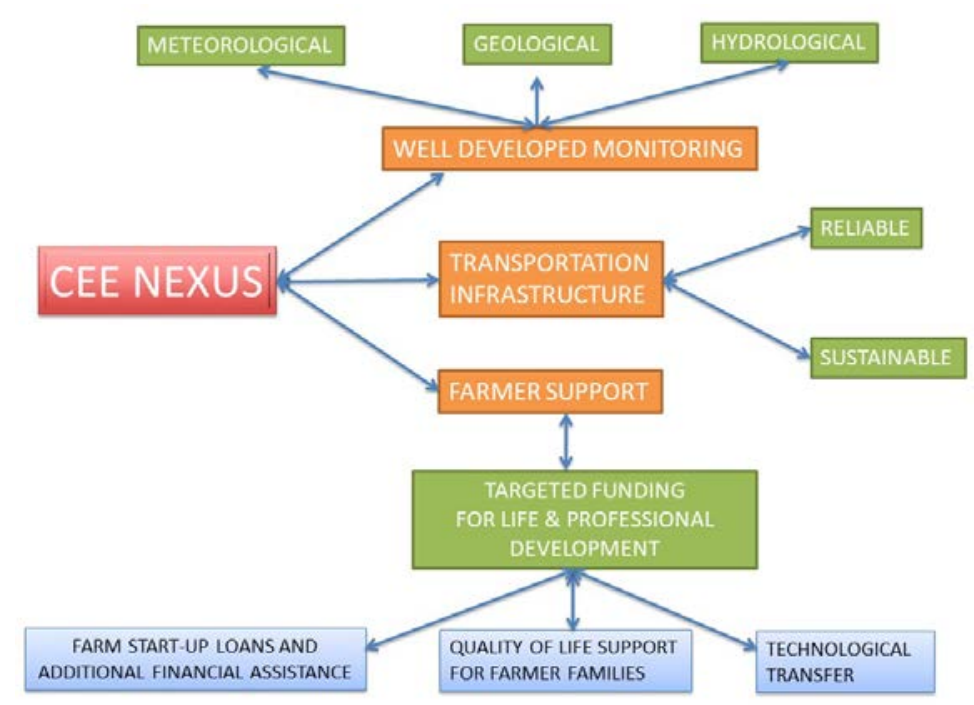

Fig. 4. WEF supporting pillars (Source: the authors)

While the CEE region is mentioned as a valuable potential supplier of biofuels to the EU (Kondili and Kaldellis 2007; Vasile et al., 2016), it is mostly perceived from a geopolitical standpoint within the context of EU energy dependence on Russia (Baran, 2007). Little if any note is mentioned of the economic and environmental value of using alternative energy for a more extended transportation framework for CEE internal consumption. Thus, if considering that one of the key principles for sustainable adaptation acknowledges that adaptation by one community (aka country, region, etc.) should not undermine the resilience of others (Rasul and Sharma, 2015), the CEE region should focus more on improving its own sustainable adaptation process. In addition, while a more sustainable physical infrastructure is needed, it needs to be built within an integrated framework for community-oriented development, economic growth, social equity, and environmental protection (Tortajada, 2014).

Furthermore, despite the EU's political aim to restrict bioenergy feedstock production to marginal or abandoned land, most of this land is still used for transitional or subsistence farming in the CEE (Don et al., 2012). Adaptation should also involve measures that reduce poverty and vulnerability (Rasul and Sharma, 2015), maintaining adequate food supplies for transitional or subsistence farmers and their families and communities could become challenging if energy production prevails over food security and engages in land use competition. Poverty already contributes to challenges in expanding biofuel production to marginal land because of the high establishment costs of perennial energy crops and lower yields (Don et al., 2012), while climate variability would further amplify the risks. Similarly, while almost all CEE countries have well developed meteorological, hydrological and geological monitoring, there is no clear evidence of how these systems support decision makers in other sectors of the national economies of CEE such as agriculture and energy (Bokal et al., 2014).

Last but not least, farmer's quality of life, access to funding, and familiarity with novel technologies (e.g. mechanization, precision agriculture) altogether form another important pillar to support the nexus. As presented in 2.2., the CEE countries lack appropriate farmer support infrastructure and are already facing massive reduction in farmer numbers as well as dire prospects for the future. The value of farmer training and farmer retention is mentioned throughout the literature. Giannakis and Bruggeman (2015), for example, have found that high economic performance is almost nine times greater for countries with a highly-trained farm population, using Bulgaria's aging farm population as one of the worst-case scenarios. In many of the CEE countries young and economically active individuals have left in large numbers in search of better paid occupations, further contributing to cropland abandonment (Müller et al., 2013).

\section{Conclusions}

In conclusion, while climate change projections have started to raise concerns about WEF security and needs for adaptation, in a variety of studies that quantify and analyze climate change impacts on water availability, crop yields or yield variability, or alternative energy needed to mitigate global warming effects, the tight relationship between these three elements is lacking in the CEE literature. In general, research is focused on individual scenarios involving only one or two of the three, rather than large-scale interconnected analyses that may have even more importance to future climate change mitigation. A good level of dysfunctionality in managing natural resources with little to no regard to their scarcity and value was expected and supported for the region, especially in the Balkans. Based on findings herein, there is sufficient evidence to entertain the idea that CEE countries have capitalized their opportunities in different ways after EU accession and that geography (proximity to stronger economies), weather events, the political context, and socio-economics have all played important roles in how post-socialist agriculture has evolved over the past twenty years. There is no clear evidence of a nexus (in the literature or in practice) to help mitigate more extreme future climate change-related events and in general no evident research base to sustain and promote attempts for providing aid to determine decisions 
that are robust across these scenarios. Therefore, future research concerning the CEE region should consider the study of the existent interlinkages between WEF and provide regionally-adapted sustainable solutions to overcome present challenges faced by an understudied geographic area.

\section{References}

Alexandrov V, Genev M (2003). Climate variability and change impact on water resources in Bulgaria. European Water 1(2):25-30.

Alexandrov V, Schneider M, Koleva E, Moisselin JM (2004). Climate variability and change in Bulgaria during the 20th century. Theoretical and Applied Climatology 79(3-4):133-149.

Allan T, Keulertz M, Woertz E (2015). The water-food-energy nexus: an introduction to nexus concepts and some conceptual and operational problems. International Journal of Water Resources Development 31(3):301-311.

Anders I, Stagl J, Auer I, Pavlik D (2014). Climate change in Central and Eastern Europe. In: Rannow S, Neubert M (Eds.). Managing Protected Areas in Central and Eastern Europe Under Climate Change. Springer, Netherlands pp 17-30.

Banse M, Van Meijl H, Tabeau A, Woltjer G (2008). Will EU biofuel policies affect global agricultural markets? European Review of Agricultural Economics 35(2):117-141.

Baran Z (2007). EU energy security: time to end Russian leverage. Washington Quarterly30(4):131-144.

Batjes NH (2002). Carbon and nitrogen stocks in the soils of Central and Eastern Europe. Soil Use and Management 18(4):324329.

Bernstein L, Bosch P, CanzianiO, Chen Z, Christ R, Riahi K (2008). IPCC, 2007: Climate Change 2007: Synthesis Report. https://www.ipcc.ch/pdf/assessment-report/ar4/syr/ar4_syr.pdf

Birsan MV, Dumitrescu A, Micu DM, Cheval S (2014). Changes in annual temperature extremes in the Carpathians since $\mathrm{AD}$ 1961. Natural Hazards 74(3):1899-1910.

Bizikova L, Roy D, Venema HD, McCandless M (2014). Water-energyfood nexus and agricultural development: A sustainable development guidebook. International Institute for Sustainable Development, Winnipeg, Manitoba, Canada.

Błażejczyk K, Kazandjiev V, Degórski M, Dimitrov P (2015). Assessment of occupational heat stress risk among agriculture workers in Poland and Bulgaria. Europa XXI 29:59-72.

Bokal S, Grobicki A, Kindler J, Thalmeinerova D (2014). From national to regional plans-the Integrated Drought Management Programme of the Global Water Partnership for Central and Eastern Europe. Weather and Climate Extremes 3:37-46.

Bouma J, Varallyay G, and Batjes NH (1998). Principal land use changes anticipated in Europe.Agriculture, Ecosystems \& Environment, 67(2):103-119.

Busuioc A, Dobrinescu A, Birsan MV, Dumitrescu A, Orzan A (2015). Spatial and temporal variability of climate extremes in Romania and associated large-scale mechanisms. International Journal of Climatology 35(7):1278-1300.

Carof M, Colomb B, Aveline A (2013). A guide for choosing the most appropriate method for multi-criteria assessment of agricultural systems according to decision-makers' expectations. Agricultural Systems 115:51-62.

Chenkova N, Nikolova N (2015). Air temperature and precipitation variability in Northeastern Bulgaria on the background of climate change. Thermal Science 19(2):381-390.

Cheval S, Birsan MV, Dumitrescu A (2014). Climate variability in the Carpathian Mountains Region over 1961-2010. Global and Planetary Change 118:85-96.

Cheval S, Dumitrescu A, Birsan MV (2017). Variability of the aridity in the South-Eastern Europe over 1961-2050. Catena 151:74-86.

Ciutacu C, Chivu L, Andrei JV (2015). Similarities and dissimilarities between the EU agricultural and rural development model and Romanian agriculture. Challenges and perspectives.Land Use Policy 44:169-176.

Climate of the Carpathian Region project (2016). Retrieved 09 February 2016 from http://www.carpatclim-eu.org/

Croitoru AE, Piticar A, Burada DC (2016). Changes in precipitation extremes in Romania. Quaternary International 415:325-335.

Csaki C, Jambor A (2009). The diversity of effects of EU membership on agriculture in New Member States. Policy Studies on Rural Transition, 4, FAO (2009), 44. Retrieved 2016 February 09 from http://www.fao.org/docrep/017/aq336e/aq336e.pdf.

Csaki C, Jambor A (2013). Impacts of the EU enlargements on the new member states agriculture. Acta Oeconomica et Informatica 16(1):3550.

Dale $G$ (2016). Modelling democratic transition in southern and central Europe: DidEast Germany experience 'transición'or 'ruptura'. The State of European Integration pp 197-219.

Davidova S, Fredriksson L, Gorton M, Mishev P and Petrovici D (2012). Subsistence Farming, Incomes, and Agricultural Livelihoods in the New Member States of the European Union. Environment and Planning C: Government and Policy30(2):209-227

Degirmendžić J, Kozuchowski K, Zmudzka E (2004). Changes of air temperature and precipitation in Poland in the period 1951-2000 and their relationship to atmospheric circulation. International Journal of Climatology 24:291-310.

Domonkos P (2003). Recent precipitation trends in Hungary in the context of larger scale climatic changes. Natural Hazards 29(2):255-271.

Don A, Osborne B, Hastings A, Skiba U, Carter MS, Drewer J, Lanigan GJ (2012). Land-use change to bioenergy production in Europe: implications for the greenhouse gas balance and soil carbon. Gcb Bioenergy 4(4):372-391.

Eitzinger J, Trnka M, Semerádová D, Thaler S, Svobodová E, Hlavinka P, Dubrovský M (2013). Regional climate change impacts on agricultural crop production in Central and Eastern Europe-hotspots, regional differences and common trends. The Journal of Agricultural Science 151(6):787-812.

Erjavec E (2005). EU accession effects and challenges for agriculture and agricultural policy in Slovenia.Jahrbuch der Österreichischen Gesellschaft für Agrarökonomie 13:1-18.

European Commission, Agriculture and Rural Development, CAP context indicators 2014 and 2015 (2016). Retrieved 2016 June 27 from http://ec.europa.eu/agriculture/cap-indicators/context/index_en.html. 
458

European Commission, Agriculture and Rural Development, Financing the Common Agricultural Policy (2017). Retrieved 2017 March 02 from https://ec.europa.eu/agriculture/cap-funding_en.

European Communities (2014). Working document. Definiting proxy indicators for rural development programmes. January 2014. Retrieved 2017 September $\quad 1$ from https:/enrd.ec.europa.eu/sites/enrd/files/assets/pdf/evaluation/WPPr oxyIndicators20140117_en.pdf.

Eurostat statistics, Agri-Environmental indicator-intensificationextensification (2016). Further Eurostat information, Main tables and Database, Planned article update: September 2016. Retrieved 2016 June 29 from http://ec.europa.eu/eurostat/statistics-explained.

Fader M, GertenD, Krause M, Lucht W, Cramer W(2013).Spatial decoupling of agricultural production and consumption: Quantifying dependences of countries on food imports due to domestic land and water constraints. Environmental Research Letters 8(1):40-46.

Ferńndez J (2002). The Common Agricultural Policy and EU Enlargement: Implications for agricultural production in the Central and East European Countries. Eastern European Economics 40(3):2850.

Fischer G, PrielerS, van Velthuizen H, Berndes G, Faaij A, Londo M, de Wit M (2010). Biofuel production potentials in Europe: Sustainable use of cultivated land and pastures, Part II: Land use scenarios. Biomass and Bioenergy 34(2):173-187.

Foley JA, Ramankutty N, Brauman KA, Cassidy ES, Gerber JS, Johnston M, Balzer C (2011). Solutions for a cultivated planet. Nature 478(7369):337-342.

Foucher M (1998). The geopolitics of European frontiers. In: Anderson M, BortE(Eds). The Frontiers of Europe. London: Pinter pp 235-250.

Gerdessen JC, Pascucci S (2013). Data envelopment analysis of sustainability indicators of European agricultural systems at regional level. Agricultural Systems 118:78-90.

Giannakis E, Bruggeman A (2015). The highly variable economic performance of European agriculture. Land Use Policy 45:26-35.

Hartel T, Plieninger T (2014). European wood-pastures in transition: A social-ecological approach. London, Routledge.

Intergovernmental Panel on Climate Change (2015). Climate change 2014: Synthesis report. Contribution of Working Groups I, II and III to the Fifth Assessment Report of the Intergovernmental Panel on Climate Change [Core Writing Team, Pachauri RK, Meyer LA (Eds)]. IPCC, Geneva, Switzerland. Retrieved 2017 March 02 from http://www.ipcc.ch/report/ar5/syr/.

Kondili EM, Kaldellis JK (2007). Biofuel implementation in East Europe: Current status and future prospects. Renewable and Sustainable Energy Reviews 11(9):2137-2151.

Kyselý J (2009). Trends in heavy precipitation in the Czech Republic over 1961-2005. International Journal ofClimatology 29(12):1745-1758.

Lhotka O, Plavcová E, KyselýJ (2016). Record-breaking 2015 heat waves in Central Europe: how to view them in the climate change context? EGU General Assembly Conference Abstracts 18:7126.

Leck H, Conway D, Bradshaw M and Rees J(2015). Tracing the WaterEnergy-Food Nexus: Description, Theory and Practice. In: Geography Compass 9:445-460. doi: 10.1111/gec3.12222.

Liefert WM, Swinnen JFM (2002). Changes in Agricultural Markets in
Transition Economies. Agricultural Economic Report No. 806, Economic Research Service, U.S. Dept. of Agriculture, Washington, DC. Retrieved 2016 June 27 from http://www.ers. usda.gov/publications/aer806/aer806.pdf.

MacLeod M, Eory V, Gruère I, Lankoski J (2015). Cost effectiveness of greenhouse gas mitigation measures for agriculture: A literature review. OECD Food, Agriculture and Fisheries Papers, No 89, Paris: OECD Publishing.

Macours K, Swinnen JFM (2000). Causes of Output Decline during Transition: The Case of Central and Eastern European Agriculture. Journal of ComparativeEconomics 28:172-206.

Marin L, Birsan MV, Bojariu R, Dumitrescu A, Micu DM, Manea A (2014). An overview of annual climatic changes in Romania: trends in air temperature, precipitation, sunshine hours, cloud cover, relative humidity and wind speed during the 1961-2013 period.Carpathian Journal of Earth and Environmental Sciences 9(4):253-258.

Mathijs E, Noev N (2002). Commercialization and Subsistence in Transaction Agriculture: Empirical Evidence from Albania, Bulgaria, Hungary and Romania. Paper prepared for presentation at the Xth EAAE Congress 'Exploring Diversity in the European Agri-Food System',Zaragoza(Spain), 28-31 August 2002.

Micu D, Dragotă CS, Havriş LE (2016). Temporal variations of multi-day precipitation extremes in southern Romania: 1961-2014. Aerul si apa, componente ale mediului. Cluj-Napoca298-305.

Mihók B, Kovács E, Balázs B, Pataki G, Ambrus A, Bartha D, Dudás G (2015). Bridging the research-practice gap: Conservation research priorities in a Central and Eastern European country. Journal for Nature Conservation 28:133-148.

Müller D, Leitão PJ, Sikor T (2013). Comparing the determinants of cropland abandonment in Albania and Romania using boosted regression trees. Agricultural Systems 117:66-77.

NASA Global Climate Change. Vital Signs of the Planet (2017). Retrieved 2017 March 02 from http://climate.nasa.gov/evidence/.

O'Dowd L (2002). The changing significance of European borders. Regional and Federal Studies 12:13-36.

OECD (2014). New perspectives on the water-energy-food nexus: Forum background note. Global Forum on Environment 27-28 November 2014, OECD HQ, Paris. Retrieved 2017 February 15 from http://www.oecd.org/env/resources.

Olsson G (2013). Water, energy and food interactions - Challenges and opportunities. Frontiers of Environmental Science \& Engineering 7(5):787-793.

Paliova I, Lybek MT (2014). Bulgaria’s EU Funds Absorption: Maximizing the Potential. International Monetary Fund. IMF Working Papers.

Pătru-Stupariu I, Tudor CA, Stupariu MS, Buttler A, Peringer A (2015). Landscape persistence and stakeholder perspectives: The case of Romania's Carpathians. Applied Geography 69:87-98.

Pointereau P, Bochu JL, Doublet S (2012). Characterization and elements for a definition and an analysis of low input farming system in EU-27. In: 10th European IFSA Symposium. SOLAGRO. Retrieved 2017 February 15 from http://www.biobio-indicator.org/publications/Pointereau_2012.pdf

Popova Z, Ivanova M, Pereira LS, Alexandrov V, Kercheva M, Doneva K, Martins D (2015). Climate change in Bulgaria: assessing trends of 
droughts aggravation, maize cropping risk and irrigation requirements. In: California Drought Conference, Agu.

Portela MM, Zeleňáková M, Santos JF, Purcz P, Silva AT, Hlavaná H (2017). Comprehensive characterization of droughts in Slovakia. International Journal of Environmental Science and Development 8:25-29.

Rasul G, Sharma B (2015). The nexus approach to water-energy-food security: an option for adaptation to climate change. Climate Policy 16:682-702.

Rockström J, Williams J, Daily G, Noble A, Matthews N, Line G, Smith J (2017). Sustainable intensification of agriculture for human prosperity and global sustainability. Ambio 46:417.

Salukvadze J (2010). Good governance and natural resources tenure in Eastern Europe and CIS region. Land Tenure Working Paper 3. Food and Agriculture Organization of the United Nations. Retrieved 2016 May 12 from ftp://fpp. fao. org/docrep/fao/011/ak015e/ak015e00.pdf.

Scarlat N, Blujdea V, Dallemand JF (2011). Assessment of the availability of agricultural and forest residues for bioenergy production in Romania. Biomass and Bioenergy 35(5):1995-2005.

Simeonov T, Vassileva K, Guerova G (2013). Application of ground-based GNSS meteorology in Bulgaria/Southeast Europe: case study 2007 heat wave. Annual of University of Sofia 106:88-100. Retrieved 2017 February 15 from http://phys.unisofia.bg/annual/archive/106/full/GSU-Fizika-106_06.pdf

Smale M (2005).Valuing crop biodiversity: on-farm genetic resources and economic change. Cabi.

Smith P, Clark H, Dong H, Elsiddig EA, Haberl H, Harper R, Tubiello F (2014). Chapter 11 - Agriculture, forestry and other land use (AFOLU). In: Climate Change 2014: Mitigation of Climate Change. IPCC Working Group III Contribution to AR5. Cambridge University Press. United Kingdom and New York, NY, USA pp 1-179.

Spinoni J, Naumann G, Vogt J (2016). Spatio-temporal seasonal drought patterns in Europe from 1950 to 2015. In: EGU General Assembly Conference Abstracts 18: EGU2016-EG12268.

Stigson P, Roth S, Karlsson A (2014). Re-Evaluating the sustainability of energy systems: The Nexus of energy, water, and land-use. Handbook of Clean Energy Systems 6:1-14.

Stoate C, Báldi A, Beja P, Boatman ND, Herzon I, Van Doorn A, Ramwell $C$ (2009). Ecological impacts of early 21 st century agricultural change in Europe-a review.Journal of Environmental Management 91(1):22-46.

Sutcliffe LM, Batáry P, Kormann U,Báldi A, Dicks LV, Herzon I, Aunins A (2015). Harnessing the biodiversity value of Central and Eastern European farmland. Diversity and Distributions 21(6):722-730.
Sutherland LA, Darnhofer I, Wilson G, Zagata L (2014). Transition pathways towards sustainability in agriculture: case studies from Europe. CABI.

SvejnarJ (2013). The Czech Republic and Economic Transition in Eastern Europe. Academic Press.

SvobodováE, Trnka M, DubrovskýM, SemerádováD, EitzingerJ, Štěpánek P, Žalud Z (2014). Determination of areas with the most significant shift in persistence of pests in Europe under climate change. Pest ManagementScience 70(5):708-715.

Swinnen J, Van Herck K (2013). Food security and sociopolitical stability: Eastern Europe and Central Asia.Food Security and Sociopolitical Stability. Oxford University Press 381-405.

The Common Agricultural Policy (CAP) (2013). CAP post-2013: Graphs and figures. Share of direct payments and total subsidies in agricultural factor income (2011-15 average). Retrieved 2016 February 09 from https://ec.europa.eu/agriculture/sites/agriculture/files/cap-post2013/graphs/graph5en.pdf.

Tomczyk AM, Bednorz E (2016). Heat waves in Central Europe and their circulation conditions. International Journal of Climatology36(2):770782.

Tortajada C (2014). Water infrastructure as an essential element for human development. International Journal of Water Resources Development 30(1):8-19.

UN Composition of macro geographical (continental) regions, geographical sub-regions, and selected economic and other groupings (2016). Geographical region and composition. Retrieved 2016 June 22 from http://unstats.un.org/unsd/methods/m49/m49regin.htm.

US Chamber of Commerce Foundation (USCCF) (2016). Corporate Citizenship Center, The Energy-Water-Food Nexus. Retrieved 2016 June 22 from http://www.nasdaqomx.com/digitalAssets/92/92448_energy-waterfood-nexus-research_1.pdf.

Vasile AJ, Andreea IR, Popescu GH, Elvira N, Marian Z (2016). Implications of agricultural bioenergy crop production and prices in changing the land use paradigm - the case of Romania.Land Use Policy 50:399-407.

Verhulst N, Govaerts B, Verachtert E, Castellanos-Navarrete A, Mezzalama M, Wall P, Deckers J, Sayre KD (2010). Conservation agriculture, improving soil quality for sustainable production systems. Advances in soil science: Food security and soil quality. CRC Press, Boca Raton, FL, USA pp 137-208. 